\title{
ANALISA KECEPATAN TRANSFER DATA PADA PERANCANGAN HOTSPOT SEDERHANA DENGAN SYSTEM SINGLE SIGN-ON DI PERKANTORAN
}

\author{
Bela Neziah Arum Pangesti ${ }^{1)}$ \\ ${ }^{1}$ Jurusan Teknik Informatika dan Komputer, Politeknik Negeri Jakarta \\ email: neziaharumbela@gmail.com ${ }^{1}$
}

\begin{abstract}
Abstrak
Permasalahan perkantoran dalam pemanfatan teknologi wireless telah banyak digunakan namun terkadang tanpa memperhitungkan besar dan banyaknya user sehingga tidak mangkus. Untuk penggunaan perkantoran kecil dapat digunakan sistem jaringan wireless sederhana. Sebagian besar kantor telah menerapkan layanan hotspot tetapi layanan hotspot yang diterapkan dengan system lama yaitu penggunaan satu account untuk semua orang yang mengakses jaringan internet kantor. Single signon adalah sistem layanan hotspot yang menerapkan satu account untuk satu user, masing-masing user mendapatkan username dan password yang berbeda.

Metode yang digunakan pada penelitian ini adalah studi pustaka, analisa kebutuhan, perancangan, implementasi, pengujian dan analisa kecepatan transfer data. Pembuatan layanan hotspot dengan sistem single sign-on dibutuhkan mikrotik, dan access point yang terhubung dengan perangkat jaringan yang terdpat pada kantor. Konfigurasi dilakukan dengan menggunakan aplikasi winbox. Perancangan sistem dilanjutkan dengan dilakukan pengujian dengan analisa terhadap kecepatan transfer data (throughput) terhadap upload data menggunakan tools wireshark.

Hasil yang didapatkan dari penelitan ini adalah layanan hotspot dengan system single sign-on dan diketahui kecepatan transfer data jenis file word lebih besar dibandingkan tipe file PDF dan PPT.
\end{abstract}

Kata kunci : hotspot, mikrotik, throughput, dan single sign-on.

\begin{abstract}
The problems office in the utilization of wireless technology has widely used but sometimes without take into the number of users, so it is not mangkus. The networking system for small office can be use wireless simple system. Most of the office has applied hotspot but that is old system, one account for all people using to internet access. Single sign-on is a System services of hotspot, this system verifying an account for each user so people have different an username dan a password.

The method used is literature review, analysis, design, implementation, testing and analysis of the data transfer rate. The hotspot with a single sign-on system using mikrotik, and access point, the connected with networking devices in the office. The configuration using a winbox tools. The design of the system continued to be tested with an analysis of the data transfer rate (throughput) to upload data using a wireshark tools.
\end{abstract}

The results obtained from this study is the hotspot service with single sign-on system and known types data transfer rate of word files is a greter than file types PDF and PPT.

Keywords : hotspot, mikrotik, throughput, and single sign-on.

\section{PENDAHULUAN}

Peningkatan mutu kinerja dan pelayanan pada perkantoran semakin meningkat seiring berkembang pesatnya teknologi informasi. Hal ini sangat berguna untuk meningkatkan kinerja pada perkantoran. Salah satu perkembangan teknologi informasi yaitu wireless. Wireless atau jaringan nirkabel adalah teknologi jaringan yang memungkinan dua atau lebih komputer untuk berkomunikasi menggunakan protokol standar jaringan tanpa menggunakan kabel. Pemanfatan teknologi wireless pada perkantoran telah banyak digunakan namun terkadang tanpa memperhitungkan besar dan banyaknya user sehingga tidak mangkus.

Penggunaaan wifi untuk mengakses internet hanya berdasarakan password, hal ini dapat menyebabkan pengguna yang terkoneksi ke hotspot terlalu banyak dan penggunaan bandwidth yang tidak termanajemen sehingga 
semua orang bebas menggunakan internet. Sebagian besar kantor telah menerapkan layanan hotspot tetapi hotspot yang diterapkan dengan sistem lama yaitu penggunaan satu account atau satu username dan satu password untuk semua orang yang mengakses jaringan internet kantor. Hal ini sama saja dengan penggunaan wifi pada umumnya.

Untuk mengatasi permalsahan tersebut penggunaan perkantoran kecil dapat digunakan sistem jaringan wireless sederhana. Pada penelitian ini dibuat hotspot sederhana dengan sistem single sign-on. Single sign-on adalah sistem baru layanan hotspot untuk user.

Penelitian ini ditinjau berdasarkan penelitian-penelitian sebelumnya. Penelitian pertama berjudul "Analisa Perbandingan EasyHotspot dan Mikrotik dalam Penerapan Hotspot Area dengan sistem AAA" oleh Lubiz et al (2014). Lubiz melakukan analisa perbandingan dua buah software dalam pembuatan hotspot, dihasilkan kelebihan dan kekurangan masingmasing software berdasarkan parameter kemudahan instalasi, kemudahan kofigurasi, manajemen user, kecepatan bandwidth untuk upload/download dan tampilan interface.

Penelitian kedua berjudul "Implementasi Jaringan Hotspot Dengan Menggunakan Router Mikrotik Sebagai Penunjang Pembelajaran (Studi Kasus : SMK Sultan Agung Tirtomoyo Wonogiri)" oleh Eko P (2013). Eko membuat Hotspot menggunakan PC router mikrotik, dihasilkan jaringan internet yang lebih aman dengan username dan password.

Penelitian ketiga berjudul "Rancang Bangun Jaringan Hotspot Pada Kampus Universitas Nusantara Manado Menggunakan Router Mikrotik" oleh Standy O (2014) . Standy membuat Hotspot dengan dilakukan pengaturan bandwidth untuk meningkatkan kegiatan pembelajaran dosen dan mahasiswa, dihasilkan jaringan internet dengan fitur authentifikasi.

Berdasarkan penelitian yang ada, penggunaan mikrotik dirasa cukup efektif untuk digunakan dalam perancangan layanan hotspot sistem single sign-on.

\section{METODE PENELITIAN}

\section{a. Studi Pustaka}

Tahap ini adalah tahap awal penelitan ini dilakukan dengan pengumpulan bahan-bahan referensi, untuk dijadiakan penyelesaian masalah penggunaan media kabel dan keraguan kemanan jaringan wireless. Bahan referensi yang didapat dalam bentuk, jurnal penelitian sebelumnya, modul praktikum dan informasi dari website.

\section{b. Analisa Kebutuhan}

Pada tahap ini dilakukan analisis kebutuhan insfrastruktur layanan hotspot sistem single signon yang dibangun. Diperoleh hasil analisis dalam penyelesaian masalah ini diperlukan alat perlengkapan :

- Spesifikasi Hadware : router board mikrotik, dan access point.

- Spesifikasi Software : winbox digunakan untuk konfigurasi hotspot dengan sistem single signon, dan wireshark untuk sniffing jaringan.

\section{c. Perancangan}

Pada tahap ini hasil analisis ditranslasikan kedalam topologi jaringan dan flowchart.

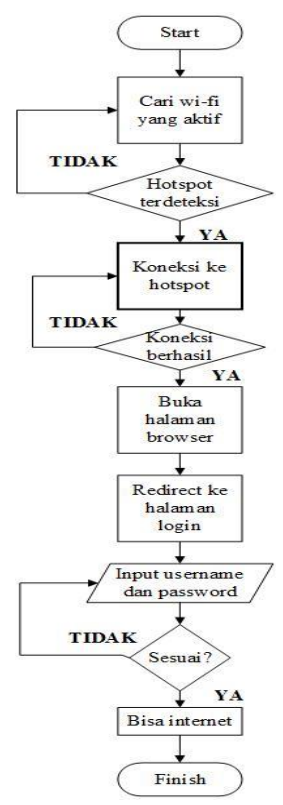

Gambar 1. Flowchart Layanan Hotspot Sistem Single Sing On

\section{d. Implementasi}

Tahap ini adalah tahap pelaksanaan sistem yang telah dibuat. Implementasi jaringan hotspot dengan sistem single sign-on menggunakan server hotspot yakni routerboard mikrotik.

\section{e. Pengujian}

Pada tahap ini sistem dilakukan uji coba apakah sistem yang dibangun sudah layak untuk dioperasikan. Apabila masih ditemukan kesalahan-kesalahan maka akan dilakukan 
perbaikan sampai sistem dinyatakan layak untuk digunakan.

\section{f. Analisa Transfer Data}

Pada tahap ini dilakukan analisa terhadap data yang diperoleh hasil perhitungan throughput. Didapatkan hasil jenis file yang memiliki throughput lebih besar adalah jenis file yang kecepatan transfer data yang paling baik. Dengan rumus throughput:

\section{Jumlah data yang berhasil lewat(bit)} Lama Waktu Pengamatan

\section{HASIL DAN PEMBAHASAN}

\subsection{Deskripsi Sistem:}

Single Sign-On adalah sistem layanan hotspot yang menerapkan satu account untuk satu user. Setiap pegawai mendapatkan account user yang berbeda-beda dan juga tamu yang datang mendapatkan account user yang berbeda-beda.

\subsection{Cara Kerja Sistem}

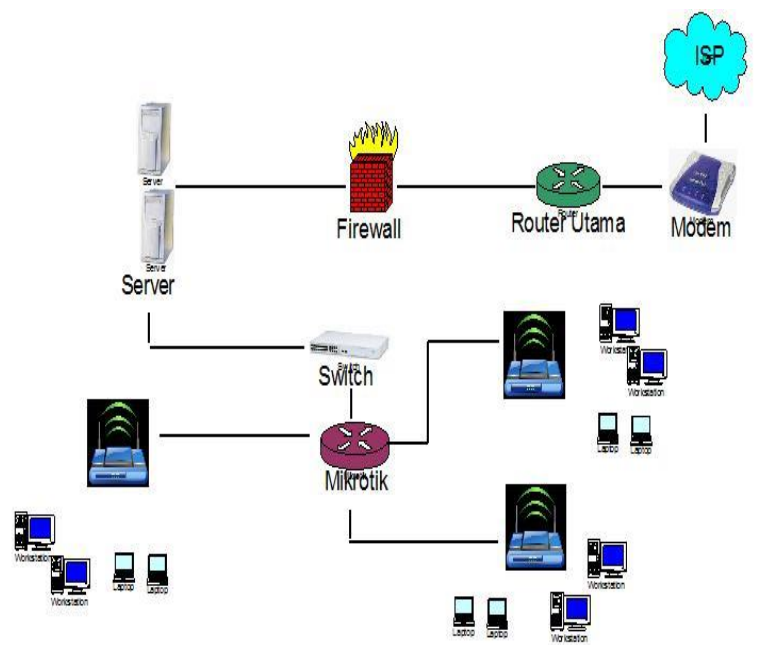

Gambar 2. Topologi Jaringan

Sistem terdiri dari mikrotik dan access point yang terhubung dengan server, router utama, modem dan ISP kantor. Perangkat komputer, laptop dan gadget user terkoneksi pada layanan hotspot sederhana. Proses analisa dilakukan dengan dua buah PC.

Pengambilan data untuk analisa dilakukan sebanyak tiga kali pada tigas jenis file yang berbeda dengan ukuran file sejenis yang sama dan bandwidth $1 \mathrm{Mb}$ pada setiap client. Sehingga dapat dibandingkan dan dilakukan analisa kualitas jenis file dari segi kecepatan transfer data.

\subsection{Pengujian}

Pengujian dilakukan dengan dua komputer dan software network analyzer yaitu wireshark untuk mengetahui throughtput yang diberikan ketika menggunakan file transfer dengan melakukan upload file ke drive. Komputer pertama dijadikan sebagai network analyzer yang sudah terinstall tools wireshark dan komputer kedua dijadikan sebagai klien. Komputer klien digunakan untuk melakukan login dengan username dan password yang berbeda-beda pada halaman login hotspot, mengupload file ke drive dan melakukan tiga kali pengujian terhadap file yang ditransfer dengan di-upload.

a. Data Hasil Pengujian Sistem

Dari hasil login user pada halaman login dan sniffing paket menggunakan wireshark pada sistem single sign-on. Setiap user mendapatkan bandwidth $1 \mathrm{Mb}$. Berikut adalah data hasil dari pengujian login masing-masing user dan throughput untuk transfer data pada sistem single sign-on diperoleh hasil pengujian login dan ratarata throughput dari ukuran file yang berbeda seperti pada tabel berikut:

Tabel 1. Pengujian User Login Sistem Single Sign-

\begin{tabular}{|c|c|c|c|}
\hline User & Data Masukan & Hasil & Kesimpulan \\
\hline \multirow{2}{*}{ Staff1 } & $\begin{array}{l}\text { Username: staff1, } \\
\text { Password: - } \\
\text { dan klik tombol } \\
\text { enter }\end{array}$ & $\begin{array}{l}\text { Tidak dapat } \\
\text { login dan } \\
\text { muncul pesan } \\
\text { eror }\end{array}$ & Diterima \\
\hline & $\begin{array}{l}\text { Username: } \text { staff1, } \\
\text { Password: staff1, } \\
\text { dan klik tombol } \\
\text { enter }\end{array}$ & $\begin{array}{l}\text { Dapat akses } \\
\text { internet }\end{array}$ & Diterima \\
\hline \multirow{2}{*}{ Staff2 } & $\begin{array}{l}\text { Username: staff2, } \\
\text { Password: - } \\
\text { dan klik tombol } \\
\text { enter }\end{array}$ & $\begin{array}{l}\text { Tidak dapat } \\
\text { login dan } \\
\text { muncul pesan } \\
\text { eror }\end{array}$ & Diterima \\
\hline & $\begin{array}{l}\text { Username: } \text { staff2, } \\
\text { Password: staff2, } \\
\text { dan klik tombol } \\
\text { enter }\end{array}$ & $\begin{array}{l}\text { Dapat akses } \\
\text { internet }\end{array}$ & Diterima \\
\hline \multirow{2}{*}{ Tamu 1} & $\begin{array}{l}\text { Username: tamu1, } \\
\text { Password: - } \\
\text { dan klik tombol } \\
\text { enter }\end{array}$ & $\begin{array}{l}\text { Tidak dapat } \\
\text { login dan } \\
\text { muncul pesan } \\
\text { eror }\end{array}$ & Diterima \\
\hline & $\begin{array}{l}\text { Username: tamu1, } \\
\text { Password: tamu1, } \\
\text { dan klik tombol } \\
\text { enter }\end{array}$ & $\begin{array}{l}\text { Dapat akses } \\
\text { internet }\end{array}$ & Diterima \\
\hline \multirow{2}{*}{ Tamu2 } & $\begin{array}{l}\text { Username: tamu2, } \\
\text { Password: - } \\
\text { dan klik tombol } \\
\text { enter }\end{array}$ & $\begin{array}{l}\text { Tidak dapat } \\
\text { login dan } \\
\text { muncul pesan } \\
\text { eror }\end{array}$ & Diterima \\
\hline & $\begin{array}{l}\text { Username: tamu2, } \\
\text { Password: tamu2, } \\
\text { dan klik tombol } \\
\text { enter }\end{array}$ & $\begin{array}{l}\text { Dapat akses } \\
\text { internet }\end{array}$ & Diterima \\
\hline
\end{tabular}


Tabel 2.Data Throughput

\begin{tabular}{|c|c|c|c|c|c|}
\hline \multirow{2}{*}{$\begin{array}{c}\text { Jenis } \\
\text { File }\end{array}$} & \multirow{2}{*}{$\begin{array}{c}\text { Ukuran } \\
\text { File } \\
(\text { KB })\end{array}$} & \multicolumn{3}{|c|}{ Pengujian Ke- (Mbit/sec) } & \multirow{2}{*}{$\begin{array}{c}\text { Rata- } \\
\text { rata } \\
\text { (Mbit/ } \\
\text { sec) }\end{array}$} \\
\hline & & 1 & 2 & 3 & \\
\hline Word & & 44.373 & 44.287 & 49.69 & 46.117 \\
\hline PDF & 1,524 & 38.385 & 39.673 & 39.892 & 39.317 \\
\hline PPT & 1,530 & 41.8 & 43.658 & 45.258 & 43.572 \\
\hline
\end{tabular}

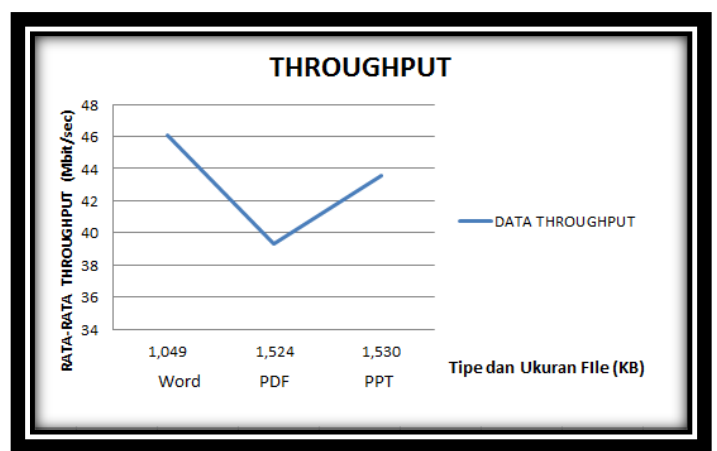

Gambar 3. Grafik Perbandingan Throughput Tiga

\section{Analisa Transfer Data}

$$
\text { Jenis File }
$$

Dari proses dan hasil pengujian data diatas, didapatkan hasil berupa analisa Perbandingan throughput pada tipe file dengan ukuran file yang tidak jauh berbeda yaitu throughput pada tipe file word lebih besar dibandingkan throughput pada tipe file pdf, dan ppt. Semakin besar throughput semakin besar kecepatan transfer data suatu jaringan, maka semakin baik jaringan tersebut.

\section{PENUTUP}

\section{Kesimpulan}

Dari penelitian yang telah dilakukan, maka dapat disimpulkan pada pengujian throughput terlihat perbedaan yang signifikan pada jenis file yang di-upload dari hasil pengujian membuktikan bahwa tipe file word mempunyai nilai throughput yang lebih baik yaitu $46.117 \mathrm{Mbit} / \mathrm{sec}$ dibandingkan tipe file PDF yaitu 39.317 dan PPT yaitu 43.572. Dengan dibangun layanan hotspot sederhana dengan sistem single sign-on user dapat mengakses layanan hotspot dengan username dan password yang berbeda-beda. Serta dengan dilakukannya Analisa Kecepatan transfer data upload dapat diketahui jenis file yang memiliki kecepatan transfer data paling baik.

\section{Saran}

Penelitian sistem hotspot ini dapat dilanjutkan keamanan jaringan hotspot. Kemudian dilakukan analisa delay, jitter, dan packet loss.

\section{REFERENSI}

Adiansyah, W. (2014). Membangun jaringan nirkabel(hotspot area) dan manajemen hotspot dengan "antamedia hotspot manager" sebagai sarana komersial berbasis wifi. Jurnal Ilmu Komputer, 10(2), 97-119.

Lubis, R. F., Raharjo, S., \& Sutanta, E. (2014). Analisa perbandingan easyhotspot dan mikrotik dalam penerapan hotspot area dengan sistem aaa. Jurnal JARKOM, 1(2), 185-189.

Marga, P., \& Naskah, T. (2014). Optimalisasi Bandwidth Dengan Filterisasi Menggunakan Mikrotik Routerboard, 4(2), 36-47.

Oei, S., \& Kunci, K. (2014). Rancang bangun jaringan hotspot pada kampus universitas nusantara manado menggunakan router mikrotik. Seminar Nasional Informatika, 107-114. 